DOI: $\underline{10.20472 / E S .2015 .4 .2 .003 ~}$

\title{
PUBLIC DEBT AND ECONOMIC GROWTH: A TWO-SIDED STORY
}

\author{
IRINA BILAN, IULIAN IHNATOV
}

\begin{abstract}
:
The recent European sovereign debt crisis proved public debt issues should not be easily approached. While, prior to the crisis, public debt was of little concern in most of the developed European countries, as there had been no recent episodes of sovereign default, the crisis revived longtime forgotten memories. It once again proved that, although at different debt levels, just like the developing countries the developed ones should fear high public debts and that public debt is almost always a two-sided story: although public indebtedness can promote economic growth, especially when debt resources are used for financing public investment expenditure, when the debt is very high it can negatively affect economic growth.

Against this background, in this paper we aim to study the relationship between public debt and economic growth for a panel of 33 European countries (28 European Union Member States and 5 candidate countries to European accession) over the period 1990-2011. More specifically, we investigate if there is evidence of a non-linear (quadratic) relationship, both for the entire European countries group and for the developed and developing countries subgroups. The main sources of data are World Bank's World Development Indicators and International Monetary Fund's World Economic Outlook and Historical Public Debt datasets.

The results of our study confirm the existence of a „U inverted" relationship, with a maximum debt threshold of about $94 \%$ of GDP. After this threshold public debt is expected to negatively affect the economic growth rate, due to higher interest rates, fear of public debt unsustainability and severe budgetary consolidation measures. However, this threshold is found to be more than twice lower in developing European countries compared to the developed ones, as the former enjoy lower credibility, higher vulnerability to shocks and depend more on external capital transfers.
\end{abstract}

\section{Keywords:}

public debt, economic growth, public policy, developed European countries, developing European countries

JEL Classification: H63, E60, O40

\section{Authors:}

IRINA BILAN, "Al. I. Cuza" University of Iasi, Romania, Email: irina.bilan@uaic.ro IULIAN IHNATOV, "Al. I. Cuza" University of Iasi, Romania, Email: iulian.innatov@uaic.ro

\section{Citation:}

IRINA BILAN, IULIAN IHNATOV (2015). Public Debt and Economic Growth: A Two-Sided Story . International Journal of Economic Sciences, Vol. IV(2), pp. 24-39., 10.20472/ES.2015.4.2.003 


\section{Introduction}

The recent sovereign debt crisis revived longtime forgotten memories for the developed European countries, bringing public debt issues to the forefront of public policy debates. Prior to the crisis, public debt issues were of little concern in many developed European countries, as there had been no recent episodes of sovereign default. However, as the crisis emerged, it once again became clear that, although at different debt levels, just like the developing countries the developed ones should fear high public debts, and that public debt is almost always a two-sided story: although public indebtedness can promote economic growth, especially when debt resources are used for financing public investment expenditure, when the debt is very high it can negatively affect economic growth.

Against this background, the paper aims to empirically investigate, using panel data estimation methods, the short-time effects of public indebtedness on the economic growth rate of a country, for a group of $33 \mathrm{EU}$ Member States and candidate countries for EU accession and for a period of over 20 years, from 1990 to 2011.

More specifically, our research seeks to achieve the following objectives:

- to establish if there is evidence for a non-linear (quadratic) relationship between the economic growth rate and the government debt-to-GDP ratio of European countries;

- to identify, four our group of countries, the maximum debt-to-GDP ratio once overpassed a further increase in public debt adversely affects economic growth;

- to see if there are significant differences between currently developed and developing European countries, both in terms of the effects of public debt on economic growth and of the maximum public debt threshold beyond which the effects are expected to become negative and, thus, to appreciate if the existence of a unique European debt limit of $60 \%$ of GDP for all EU Member States is justifiable, from this point of view.

The remainder of this paper is structured as follows. Section 2 overviews the empirical literature on the effects of public and, more extensively, external debt on the economic growth rate of a country. In section 3 we explain the methodology we have used to investigate the effects of public debt levels on economic growth and we discuss the data. In section 4 we present the results of our empirical analysis and discuss their potential implications for public policy-making. The final section of our paper concludes and draws some policy recommendations and suggestions for further research.

\section{Literature review}

The empirical literature dealing directly with the effects of public indebtedness on economic growth became more consistent only in recent years, in the context of the adverse European and international developments. Several reasons could explain this situation, including (Abbas and Christensen, 2007): the lack of comparable datasets for a large number of countries; considering public debt mainly as an endogenous variable and not as an exogenous one, whose size affects macroeconomic outcomes; the fact 
that the size of public debt has not been, until recently, assessed as problematic in most developed countries, there where most of the research efforts are concentrated.

Before the outbreak of the recent global economic crisis, although some studies have been conducted on the impact of debt on economic growth, most often they referred to foreign debt and only tangentially to public debt. They also frequently focused on developing countries, especially those with low incomes (Weeks, 2000; Patillo et al., 2002; Karagol, 2002; Patillo et al., 2004; Clements et al., 2003; Schclarek, 2004). Subsequently, although the impact of public debt on economic growth has been tackled more directly, the studies have focused, most often, on the situation of developed countries (Ferreira, 2009; Misztal, 2010; Checherita and Rother, 2010; Reinhart and Rogoff, 2010a; Reinhart and Rogoff, 2010b; Kumar and Woo, 2010; Baum et al., 2012; Panizza and Presbitero, 2014).

Regarding the results of the most representative empirical studies addressing issues similar to the ones of our research, they are mixed ones, differing upon the group of countries and the time framework of the analysis, but also upon the research methodology. We may observe, however, that most of them tend to indicate the existence of an inverse relationship between the size of public debt (or, in some cases, foreign debt) and the growth rate of GDP in a given country or group of countries, which points to the existence of some adverse effects of public debt on economic growth.

In this respect, analyzing the situation of 59 developing countries for the period 1970 to 2002, Schclarek (2004) identified a negative impact of foreign debt growth on the growth rate of GDP per capita, considering that it is mainly due to the external public debt component, the growth of which affects capital accumulation. Although his analysis also included 24 industrialized countries, for which the issue of public debt has been more directly addressed, the results for this group did not indicate a significant relationship between public debt and the growth of GDP per capita. Also, Weeks (2000) found, for a group of 18 Latin American countries, that a 1\% increase in external debt service results, in the long run, in an economic growth rate lower by $1.6 \%$. Similar effects for the case of developing countries have been evidenced by Scott (1995) and Karagol (2002). Hepp (2008), concerned with identifying the existence of a positive impact on economic growth of the external debt reduction initiatives of the $90 \mathrm{~s}$ in developing countries, found that such impact was virtually nonexistent, although more consistent results were found in those beneficiary countries with higher incomes.

Directly tackling the issue of public debt, Ferreira (2009) analyzed its relationship with the growth of per capita GDP for a group of OECD countries, over the period 19882001. Based on the VAR methodology and Granger causality test, he confirmed the existence of a bidirectional relationship, meaning that a higher GDP growth rate reduces public debt but, at the same time, an increase of the latter negatively affects economic growth. Also, his findings pointed to a heterogeneous behavior across different OECD countries, partially linked to different initial conditions. Based on a similar methodology, his results have been confirmed by Misztal (2010), who's analysis conducted on the EU Member States over the period 2000-2010 concluded that an increase in public debt by $1 \%$ in these countries has led, on average, to a reduction in GDP by $0.3 \%$, while a GDP 
growth by $1 \%$ resulted in a reduction of public debt, on average by $0.4 \%$. Also, he found that one of the most important factors with impact on the size of public debt in the EU was GDP's dynamics.

An inverse relationship between public debt and economic growth over the long-run, for a panel of 38 developed and emerging countries, resulted from the research conducted, over the period 1970 to 2007, by Kumar and Woo (2010), using BE and SGMM along with other estimation techniques. They found that, on average, a $10 \%$ increase of the initial public debt-to-GDP ratio is associated with a reduction of the real GDP per capita growth rate of about $0.2 \%$ per year, the impact being stronger in emerging market economies and weaker in developed ones. Also, they found evidence of nonlinearity, higher levels of initial debt having a proportionately greater negative effect on subsequent economic growth. Analyzing the reasons underlying the identified inverse relationship, the authors found that an increase in public debt is associated with lower investments and, therefore, a reduction in the rate of capital accumulation.

For the case of Italy (1861-2009), Balassone et al. (2011) also found evidence of a negative impact of public debt on economic growth, the effect being stronger once public debt exceeds $100 \%$ of GDP. The effect was found to be stronger in the case of foreign debt compared to domestic debt, being mainly induced through reduced investment. Panizza and Presbitero (2014), using an instrumental variable approach for a sample of OECD countries, found, at their turn, a negative correlation between public debt and growth. However, they also found that the link between debt and growth disappears once corrections for endogeneity are operated, concluding that, in fact, there is no real evidence that public debt has a causal effect on GDP growth.

At the opposite side, although small in number, some papers can be identified that find evidence for positive effects of public indebtedness on economic growth, such as that of Abbas and Christensen (2007). A positive impact of external indebtedness on economic growth has also been observed, using meta-analysis, in the case of the developing countries by Moore and Chrystol (2010), who concluded that it results from the use of external resources to increase the productive capacity of a nation.

A new research direction, reflected in the empirical studies of recent years, aims at identifying the existence of a non-linear ("U inverted") relationship between public debt and economic growth, which implies the acceptance of possible positive effects of public indebtedness on GDP growth rates up to a certain debt threshold, beyond which the effects are expected to reverse. Although such a relationship has initially been documented in the context of analysis conducted on the effects of foreign debt on economic growth, more recent studies have confirmed the existence of a similar relationship between public debt and growth.

Following this research direction, Patillo et al. (2002) found, for a sample of 93 developing countries and during 1969-1998, evidence for a non-linear (,Laffer type”) relationship between external debt and economic growth. In a subsequent study, the same authors (Patillo et al., 2004) have estimated that the critical threshold beyond which increasing external debt inhibits growth is of approximately 35-40\% of GDP. Similar results have been obtained by Clements et al. (2003) who, analyzing the 
situation of 55 low income countries for the period 1970 to 1999 , have identified a critical threshold of external debt of about $50 \%$ of GDP.

As for studies finding evidence of non-linear effects of public debt on economic growth, more representative are those of Smyth and Hsing (1995), Reinhart and Rogoff (2010a, 2010b), Checherita and Rother (2010), Greenidge et al. (2012) or Baum et al. (2012). The former authors, concerned with finding the value of public debt that ensures the maximization of the growth rate of GDP, on the example of the United States (19801990), identified, in reality, a non-linear relationship between the two indicators, with a corresponding optimal public debt ratio of almost $50 \%$ of GDP.

More recently, the studies undertaken by Reinhart and Rogoff (2010a, 2010b), analyzing the long-term relationship between the central government debt and the real GDP growth rate for a group of 44 developed and emerging market countries and over a period of more than two centuries (1790-2009), have identified the existence of a weak connection between the two indicators before the debt reaches $90 \%$ of GDP. After this threshold, the connection has been found to become stronger, meaning that the real economic growth rate in countries with public debt ratios above $90 \%$ of GDP is, on average, a few percent lower than in other countries. However, their results have been strongly contested by other authors (Herndon et al., 2013) who, replicating their research, found that the average GDP growth at public debt higher than $90 \%$ of GDP is not dramatically different than in the case where the ratios are lower.

Seeking to assess the impact of public indebtedness on economic growth for 12 Euro area member states, over the period 1970 to 2008, Checherita and Rother (2010) have also identified the existence of a non-linear relationship, with a maximum public debt level beyond which its effects on GDP growth rates become negative, of approximately $90-100 \%$ of GDP. The research undertaken by these authors has highlighted several channels through which high public debt negatively affects economic growth, including private savings, public investments and total factor productivity. Based on a different methodology and different time framework (1990-2010), but for the same group of countries, Baum et al. (2012) identified a positive short-term impact of public debt on economic growth up to a public debt ratio of $67 \%$ of GDP, the effect becoming insignificant afterwards and even negative beyond 95\% of GDP. For some heavily indebted developing countries in the Caribbean, Greenidge et al. (2012) have identified a similar, only much smaller threshold, of about 55-56\% of GDP, although the positive effects of public debt on growth have been found to become very weak even earlier, once public debt exceeds $30 \%$ of GDP.

However, the hypothesis of the existence of debt thresholds is not unanimously confirmed in empirical studies dealing with this research problem. Considering a sample of advanced economies, Pescatori et al. (2014) find no evidence of any particular debt threshold above which growth prospects, over the medium-term, are dramatically compromised. Also, they found that the debt trajectory is as important as the debt level in understanding growth prospects. 


\section{Methodology and data}

In order to assess the impact of public debt on economic growth we have used a generalized model of economic growth, complemented with an explanatory variable to measure the impact of public debt. Assimilating the latest research directions, when shaping our empirical model we took into consideration the possibility that the relationship between public debt and economic growth is not a linear one, but rather a "U inverted" type one. This means that, although up to a critical level public debt may have positive effects on economic growth, above this level the relationship is expected to reverse. Thus, we have specified the model in a quadratic form, using as regressors not only the debt variable, but also its squared value.

The estimation equation is the following:

$$
\underset{\varepsilon_{i, t}}{g d p_{-} g r_{i, t}=\alpha+\beta_{1} \operatorname{lng} g p_{i, t-1}+\beta_{2} p o p_{-} g r_{i, t}+\beta_{3} d e b t_{i, t}+\beta_{4} d e b t_{i, t}^{2}+X_{i, t} \beta^{\prime}+\theta_{i}+}
$$

where:

gdp_gr = the dependent variable (the growth rate of per capita GDP)

Ingdp = the natural logarithm of per capita GDP

pop_gr = the population growth rate

debt $=$ the public debt-to-GDP ratio

$X=$ the vector of control variables that influence economic growth

$\theta=$ country fixed effects

$\varepsilon=$ the error term

$\alpha=$ the constant term

$\beta=$ the coefficients of independent variables

$\mathrm{i}=$ country

$\mathrm{t}=$ year

As results from equation (1), the dependent variable in our model is represented by the growth rate of per capita GDP of the same year $\left(g d p_{-} g r_{i, t}\right)$, meaning that the short-term effects of public debt are evaluated. However, economic theory admits and practice confirms that time-lags may exist (more relevant studies being that of Checherita and Rother (2010) and Kumar and Woo (2010)), meaning that some of the effects may become relevant after a certain time-framework, of even several years. This is especially relevant when public indebtedness interferes with the level of public and private investment, with medium and long-term economic effects, as in the case of debt financed public capital expenditures. From this point of view, it would be interesting to evaluate the medium and long-term impact of public debt (e.g. over a period of 5 years). However, this approach was hindered by the low availability of data for some of the countries included in our analysis, such as the candidate countries to the EU integration. In our empirical model we have considered as regressors, in addition to the natural logarithm of per capita GDP of the previous year $\left(\operatorname{lng} d p_{i, t-1}\right)$ and population growth rate $\left(\right.$ pop_gr $_{i, t}$ ), commonly included in economic growth models, and the public debt 
variables $\left(d e b t_{i, t}\right.$ and $\left.d e b t_{i, t}^{2}\right)$, a set of control variables to capture the impact of other determinants of economic growth: the gross fixed capital formation (fixed_cap) to reflect the impact of physical capital accumulation; the public budget balance (bug_bal) to capture the broader impact of fiscal-budgetary policies; the sum of exports and imports as a share of GDP (exp_imp) and the exchange rate (exch), to express the impact of the degree of openness of the economy and external competitiveness. The selection of our control variables was performed taking into account the results of other relevant empirical studies on the determinants of economic growth (Clements et al., 2003; Kumar and Woo, 2010; Checherita and Rother, 2010). A short description of all variables included in our regression model can be found in Table 1.

Table 1. List of variables and data sources

\begin{tabular}{|c|c|c|c|}
\hline Symbol & $\begin{array}{l}\text { Variable } \\
\text { name }\end{array}$ & $\begin{array}{c}\text { Variable } \\
\text { description }\end{array}$ & Data sources \\
\hline \multicolumn{4}{|c|}{ Dependent variable } \\
\hline gdp_gr & $\begin{array}{l}\text { Economic } \\
\text { growth }\end{array}$ & $\begin{array}{l}\text { GDP per capita } \\
\text { growth (annual \%) }\end{array}$ & $\begin{array}{l}\text { World Bank (World Development } \\
\text { Indicators) }\end{array}$ \\
\hline \multicolumn{4}{|c|}{ Independent variables } \\
\hline debt & Public debt & $\begin{array}{l}\text { General government } \\
\text { gross debt }\left(\begin{array}{ll}\% & \text { of } \\
\text { GDP })\end{array}\right.\end{array}$ & $\begin{array}{l}\text { International Monetary Fund } \\
\text { (Historical Public Debt Database); } \\
\text { AMECO for Bulgaria (2000), } \\
\text { Cyprus (1995) and Luxembourg } \\
\text { (1990) }\end{array}$ \\
\hline gdp & $\begin{array}{l}\text { GDP per } \\
\text { capita }\end{array}$ & $\begin{array}{|lr|}\text { GDP per } & \text { capita } \\
\text { (constant } & 2000 \\
\text { USD) } & \\
\end{array}$ & $\begin{array}{l}\text { World Bank (World Development } \\
\text { Indicators) }\end{array}$ \\
\hline pop_gr & $\begin{array}{l}\text { Population } \\
\text { growth }\end{array}$ & $\begin{array}{ll}\text { Population } & \text { growth } \\
\text { (annual \%) } & \end{array}$ & $\begin{array}{l}\text { World Bank (Health, Nutrition and } \\
\text { Population Statistics) }\end{array}$ \\
\hline exp_imp & $\begin{array}{l}\text { Openness of } \\
\text { the economy }\end{array}$ & $\begin{array}{l}\text { Sum of imports and } \\
\text { exports of goods and } \\
\text { services (\% of GDP) }\end{array}$ & $\begin{array}{l}\text { World Bank (World Development } \\
\text { Indicators); AMECO for Cyprus } \\
\text { (2011) and Poland (2011) }\end{array}$ \\
\hline fixed_cap & $\begin{array}{l}\text { Fixed capital } \\
\text { formation }\end{array}$ & $\begin{array}{l}\text { Gross fixed capital } \\
\text { formation }(\% \text { of } \\
\text { GDP })\end{array}$ & $\begin{array}{l}\text { World Bank (World Development } \\
\text { Indicators); AMECO for Cyprus } \\
\text { (2011) and Poland (2011) }\end{array}$ \\
\hline bug_bal & $\begin{array}{l}\text { Budget } \\
\text { balance }\end{array}$ & $\begin{array}{l}\text { General government } \\
\text { budget balance ( } \% \\
\text { of GDP) }\end{array}$ & $\begin{array}{l}\text { International Monetary Fund } \\
\text { (World Economic Outlook } \\
\text { Database) }\end{array}$ \\
\hline exch & $\begin{array}{l}\text { Exchange } \\
\text { rate }\end{array}$ & $\begin{array}{l}\text { Real exchange rate } \\
\text { (index, 2005=100) }\end{array}$ & $\begin{array}{l}\text { World Bank (World Development } \\
\text { Indicators) }\end{array}$ \\
\hline
\end{tabular}

Source: the authors 
To solve the problem of endogeneity specific to economic growth models, mainly that of reverse causality (the possibility that the growth of GDP affects - diminishes - the relative size of public debt), we have resorted to instrumental variable estimation techniques. More specifically, the estimators we have used in our paper are GMM estimators. Based on previous studies (Patillo et al., 2004; Checherita and Rother, 2010), we have instrumented the debt and debt squared variables for each country through their time lags (up to the 5th lag). The Hansen test allowed us to test the statistical significance of the instruments selected.

Given the large number of countries included in our analysis, heterogeneity could be a problem, so we have used the fixed effects version of the estimation method, allowing us to isolate the effect of the omitted variables, specific to each country. We have made no restrictive assumptions of homoscedasticity and lack of autocorrelation of errors and, therefore, we have selected in our estimation options using estimators robust against relaxed assumptions. The generalized method of moments produces consistent coefficient estimates (coefficients asymptotically approaching their actual values).

The hypothesis that the functional relationship between public debt and economic growth is non-linear, of a concave curve type ("Laffer" type), is confirmed while the coefficient $\beta 3$ associated to the debt variable is positive and $\beta 4$ associated to debt $^{2}$ variable is negative. This allows us to determine the maximum affordable public debt that does not have a negative impact on economic growth ( $\left.d e b t_{\max }\right)$, according to relation (2).

$$
d e b t_{\max }=-\frac{\beta_{3}}{2 \beta_{4}}
$$

Our analysis is conducted for a panel of 33 countries, including the $28 \mathrm{EU}$ Member States and five candidate countries to join the European Union (Macedonia, Iceland, Montenegro, Serbia and Turkey), and covers a time framework of over 20 years (19902011). However, for some of the considered countries, especially those belonging to the new EU Member States and the candidate countries groups, data were available for a shorter period of time, sometimes after 2000.

The data mainly come from the databases of international financial institutions available online, namely the World Bank's World Development Indicators Database and the IMF's World Economic Outlook Database and Historical Public Debt Database. Detailed information on the sources of data used for each of the variables included in our model can be found in Table 1.

Extending the analysis towards candidate countries, most of them developing ones (with the exception of Iceland), raised the issue of identifying other data sources than the ones typically used in empirical studies on the situation of EU Member States (Eurostat, Ameco). However, it allowed us to achieve the objective of highlighting the particularities of public debt's effects on economic growth for the two major categories of countries, developed and developing ones. 
More specifically, our analysis is particularized for two country groups, comprising 22 developed countries and 11 developing ones. From this point of view, a key contribution of our research in relation to recent empirical studies dealing with similar issues, is that it extends the analysis to developing countries, bringing to the forefront their specific problems in times when, on the background of unsustainable public debt levels in many developed countries, the scope of interest in research shifted almost unanimously towards the latter and concerns about the situation of the former were abandoned.

\section{Results and discussions}

The results of our quadratic model estimation, for all EU Member States and candidate countries and for the two developed and developing countries subgroups, are summarized in Table 2. The estimation was performed using the statistical software STATA/ SE 12.1.

\section{Table 2. Estimation results}

\begin{tabular}{|c|c|c|c|}
\hline & $\begin{array}{l}\text { EU Member States and } \\
\text { candidate countries (all) }\end{array}$ & $\begin{array}{c}\text { EU Member States and } \\
\text { candidate countries } \\
\text { (developed) }\end{array}$ & $\begin{array}{c}\text { EU Member States and } \\
\text { candidate countries } \\
\text { (developing) }\end{array}$ \\
\hline \multirow[t]{2}{*}{ debt2 } & $-0.000669^{* * *}$ & $-0.000581^{\star \star \star}$ & $-0.00337^{\star \star \star}$ \\
\hline & $(0.000195)$ & $(0.000218)$ & $(0.00114)$ \\
\hline \multirow[t]{2}{*}{ debt } & $0.126^{\star \star \star}$ & $0.114^{\star \star *}$ & $0.301^{* \star *}$ \\
\hline & $(0.0339)$ & $(0.0394)$ & $(0.105)$ \\
\hline \multirow[t]{2}{*}{ L.Ingdp } & $-15.11^{\star \star \star}$ & $-15.14^{\star \star \star}$ & $-14.30^{\star \star \star}$ \\
\hline & $(1.552)$ & $(1.599)$ & $(4.606)$ \\
\hline \multirow[t]{2}{*}{ fixed_cap } & $0.392^{* * *}$ & $0.358^{* \star *}$ & $0.371^{* *}$ \\
\hline & $(0.0614)$ & $(0.0662)$ & $(0.148)$ \\
\hline \multirow[t]{2}{*}{ pop_gr } & $-1.200^{* \star *}$ & $-1.316^{\star \star \star}$ & -0.137 \\
\hline & $(0.276)$ & $(0.370)$ & $(0.634)$ \\
\hline \multirow[t]{2}{*}{ exp_imp } & $0.0803^{* * *}$ & $0.0790^{* * *}$ & $0.126^{* * *}$ \\
\hline & $(0.0141)$ & $(0.0151)$ & $(0.0430)$ \\
\hline \multirow[t]{2}{*}{ bug_bal } & $0.318^{* \star *}$ & $0.347^{\star \star \star}$ & 0.125 \\
\hline & $(0.0534)$ & $(0.0611)$ & $(0.140)$ \\
\hline \multirow[t]{2}{*}{ exch } & $0.0688^{* \star \star}$ & $0.0877^{\star \star \star}$ & 0.00831 \\
\hline & $(0.0180)$ & $(0.0184)$ & $(0.0577)$ \\
\hline$N$ & 405 & 330 & 75 \\
\hline $\operatorname{adj} . R^{2}$ & 0.431 & 0.483 & 0.292 \\
\hline debt $_{\max }$ & 93.89 & 98.55 & 44.74 \\
\hline HansenPval & 0.6788 & 0.9410 & 0.2008 \\
\hline
\end{tabular}

Note:

Standard errors between parentheses

$d e b t_{\max }$ - the maximum value of the quadratic model

${ }^{*} p<0.10,{ }^{* *} p<0.05,{ }^{* * *} p<0.01$ 
The results show that, for all models, both the coefficients associated to the explanatory variable debt and those of debt $^{2}$ are significant at a significance level $p<0.01$. It is thus confirmed the hypothesis of a non-linear, quadratic relationship between public debt and economic growth, relationship validated for both the EU Member States and candidate countries to EU accession group and the developed and developing countries subgroups.

With regard to the sign of the coefficients of our central explanatory variables, it can be seen that the coefficients of the debt variable always have positive values, while those associated to debt ${ }^{2}$ always have negative ones, implying that the functional relationship linking the growth rate of GDP to the size of government debt is one of concave type, admitting the existence of a maximum value. It is thus confirmed, for our countries and time framework, the initial assumption that when the ratio of public debt-to-GDP is small, the effects of an increase in the debt levels on the growth rate of GDP may be positive, but these effects gradually diminish as public debt is becoming increasingly high, and there is a certain public debt level beyond which the impact on GDP of further growing debt reverses, becoming negative. For the group of all EU Member States and candidate countries to European accession, the level of public debt allowing for the maximization of the growth rate of GDP is about $94 \%$ of GDP.

Possible explanations for the positive effects of public indebtedness on economic growth, as long as the accumulated debt is not oversized, arise especially from the use of borrowed resources to finance increased public spending with beneficial impact on the productive capacity of a nation, although, on the short-run, the positive impact of increased global demand is not to be neglected. From this point of view, it is necessary to note the concern of EU Member States for prioritizing public spending with potentially more favorable impact on economic growth (such as capital expenditure, expenditure for education, research and development, etc.), reflected by the content of Lisbon and Europe 2020 growth strategies. Also, the currently candidate countries for EU accession and Central and Eastern European countries that joined EU in 2004, 2007 and 2013, incurred debt to finance major public investment expenditure, especially for infrastructure, with the aim to fill the development gaps between them and the other EU Member States.

Once a certain threshold is exceeded, our study confirms that public debt's effects on the growth rate of GDP become predominantly negative ones. There are several possible explanations for this situation, out of which we will only refer to the most relevant ones for the European countries, which make the subject of our study. Thus, considering the European realities of recent years, a natural explanation stems from the fact that a high public debt raises concerns about its sustainability and the future conduct of the monetary and financial policies, fueling a general climate of mistrust, with negative impact on savings and private investment and, thereby, on economic growth. When public debt breaches a certain threshold, the private sector could start dissaving due to the anticipation of future inflationary pressures, as confirm some empirical studies such as that of Checherita and Rother (2010), conducted on the Euro area countries. The general mistrust regarding the ability of public authorities to honor their public debt repayment commitments without resorting to severe budgetary adjustment 
measures, such as increasing existing tax rates or introducing new taxes, could determine, at the same time, the reduction of capital inflows to the affected country or even the increase of capital outflows to other countries. These effects are especially important for countries eliminating restrictions on the free movement of factors, as is the case of the European Union member countries.

Also, when the public debt of a country rises above a certain level, lending to governments is perceived by investors on the financial markets as being more risky, which leads to the increase of government bond yields, as a risk premium is included. The developments in recent years confirm that for some European countries affected by sovereign debt crisis like Greece, Spain, Portugal, Ireland and even Italy, the yields of government bonds issued by these countries on the financial markets were much higher than the ones of other, safer countries, like Germany. The government bond spreads determined as the difference between the yields on government bonds with a maturity of ten years and the yields of equivalent bonds issued by Germany have exceeded, for example, in 2011, 3.500 basis points for Greece and 1000 basis points for Ireland and Portugal (ECB, 2012). This increase in the government bonds interest rate, considered as benchmark for the risks undertaken when lending to the private sector of a country, may raise the interest rate when the latter borrow on the financial markets, thus limiting the access of private agents to financial resources and leading to lower private investment and capital accumulation.

Large public debts may also force governments to adopt severe fiscal consolidation measures, by either increasing tax rates or introducing new taxes, with negative effects on the incentive to work, save and invest, or reducing some public expenditure with potentially more favorable impact on economic growth, such as investment ones. This reaction has been confirmed, in recent years, for many of the European countries included our analysis with important public debts and negative budget balances. Reducing public investment spending has been considered to be an easier way to reduce overall budget deficits in many European countries. According to European Commission's data, 17 out of a total of 30 countries of the ones included in our analysis (excluding Croatia, Serbia and Montenegro) recorded in 2007-2011 a reduction of their public capital expenditure, expressed as a share of GDP.

The results of our study point to the existence of significant differences, between subgroups of countries, regarding the maximum level of public debt beyond which its effects on economic growth become, on average, negative. In the developed EU Member States and candidate countries for EU accession, the level is much higher, of about $98 \%$ of GDP. On the contrary, the threshold is much lower in developing countries, of about $44 \%$ of GDP, which shows that the reversal of the effects is expected to occur much earlier than in the case of the former. The results of our research thus confirm the findings of other recent empirical studies on the situation of developed countries, that identify a maximum debt level of approximately $90-100 \%$ of GDP, as the ones of Reinhart and Rogoff' (2010a, 2010b), Checherita and Rother (2010) or Baum et al. (2012). In the case of developing countries, the maximum public debt ratio we've identified is lower than the one of Greenidge et al. (2012), of about 55\% of GDP, 
although we must admit that this is perfectly reasonable as the former authors refer to a different regional group.

A possible explanation for this situation lies in the much lower credibility that developing countries enjoy from potential creditors, investors, etc., which makes the negative effects of a high public debt to occur more rapidly than in the case of developed countries. This lower credibility is fueled by the recent record of some government debt repayment problems in some of the developing countries (e.g. Romania, 1999), at quite low debt levels by European developed countries' standards. Also, developing countries are more vulnerable and depend, to a larger extent, on foreign capital for development. Thus, the effects on economic growth of lower willingness of foreign creditors and investors to provide capital, due to the higher risk they perceive when public authorities' debt is important, are more unfavorable.

Although significant differences between developed and developing countries have been identified, one should accept that even the two subgroups are quite heterogeneous, so the relevance of the effects and debt thresholds should be differently interpreted in relation to the particular conditions and situation of each individual country. For instance, the magnitude of public debt dynamics and debt history of a country, along with the structure and composition of public debt, could play an important role. The particular relationship and value of debt threshold may also depend on the institutional quality, on public sector's dimension and on how and for what purposes public debt has been accumulated (Panizza and Presbitero, 2013).

Considering the channels through which the effects are transmitted (like that of investors' confidence), a sharp rise in public debt to GDP ratios is more likely to hinder economic growth compared to a more steady growth and over a longer period of time. The strong negative effects on economic activity of the recent unsustainable public debt growth in European countries, on the background of the economic and financial crisis, confirm that the rapidly increasing public debts are the more harmful for economic stability and growth. Also, in countries with high external to overall public debt ratios, the negative effects of growing debt may occur sooner and be stronger than in countries with high shares of domestic public debt (as empirically confirms Balassone et al. (2011)). From this point of view, the developing countries group shows high disparities: while in countries like Bulgaria and Croatia, foreign currency public debt represents more than $70 \%$ of overall public debt, in others, like the Czech Republic, the share is inferior to $20 \%$.

Overall, the results of our empirical study also question the viability of establishing, through the European treaties, of a unique public debt limit of $60 \%$ of GDP for all EU Member States, without regard to the significant differences between their level of economic development. If, for the developed countries, this threshold may act as a brake, limiting public authorities' capacity to incur more debt in order to support economic growth or to achieve other socio-economic objectives, for the developing countries it might prove, on the contrary, to be too permissive. It would be necessary, in our opinion, to establish different debt limits for different countries, at least for the two major groups - developed and developing - states, if not even for their subgroups. We 
suggest, in this respect, a maximum public debt ratio of about $40-50 \%$ of GDP for developing EU Member States and $70-80 \%$ for the developed ones.

\section{Conclusions}

The analysis we have conducted for a panel of 33 developed and developing European countries, over the period 1990-2011, confirmed the existence of a "U inverted" relationship between public debt and economic growth, with a maximum debt threshold of about $94 \%$ of GDP for the whole group. After this threshold, public debt is expected to negatively affect the economic growth rate, due to higher interest rates, fear of public debt unsustainability and severe budgetary consolidation measures. However, this threshold was found to be more than twice lower in developing European countries compared to the developed ones, as the former enjoy lower credibility, higher vulnerability to shocks and depend more on external capital transfers.

Consequently, it is necessary that government debt policies aim at keeping public debt levels below the above identified limits, in order to prevent possible deleterious effects on economic growth. For the European Union Member States, the results of our research bring forward the necessity to reconsider the $60 \%$ of GDP debt limit set by the Treaty of Maastricht and the Stability and Growth Pact, undifferentiated for all countries, regardless of their level of development. It was suggested, in this regard, a maximum public debt threshold of about $40-50 \%$ of GDP for developing EU countries and of about70-80\% of GDP for the developed ones.

However, the above identified public debt thresholds should not be appreciated as absolute landmarks for judgments, but interpreted with caution. In reality, depending on the particularities of each country and period of time, but especially on the destination given to borrowed resources, the adverse effects could occur at even lower public debt ratios, while the contrary is also not to be excluded.

The main limitation of our research stems from the lack of comparable datasets for the developing EU Member States and candidate countries to EU accession, that cover the entire time framework of our analysis (1990-2011). The limited availability of data for these countries did not allow us to evaluate the effects of public indebtedness on longterm economic growth (for a minimum of 5 years), although it is generally accepted that it takes time for the full effects of public investment expenditure on the real economy to appear.

Therefore, as future research direction we intend to compliment this deficiency, but also to continue our research on the effects of public debt on economic growth by identifying, for the same group of countries covered by this study, the channels through which the effects are transmitted (interest rate, private investment and capital accumulation, public investment, etc.).

\section{Acknowledgement}

This work was supported by the European Social Fund through Sectoral Operational Programme Human Resources Development 2007-2013, project number 
POSDRU/159/1.5/S/142115, project title "Performance and Excellence in Doctoral and Postdoctoral Research in Economic Sciences Domain in Romania".

\section{References}

Abbas, S.A., Christensen, J.E. (2007), The Role of Domestic Debt Markets in Economic Growth: An Empirical Investigation for Low-Income Countries and Emerging Markets, IMF Working Paper no. 127, Washington, D.C.

Balassone, F., Francese, M., Pace, A. (2011), Public debt and economic growth in Italy, Economic History Working Papers no. 11, Banca d'Italia.

Baum, A., Checherita-Westpal, C., Rother, P. (2012), Debt and Growth. New Evidence for the Euro Area, ECB Working Paper Series no. 1450.

Checherita, C., Rother, P. (2010), The impact of high and growing government debt on economic growth. An empirical investigation for the euro area, ECB Working Paper Series no. 1327.

Clements, B., Bhattacharya, R., Nguyen, T.Q (2003), External debt, public investment and growth in lowincome countries, IMF Working Paper no. 249, Washington, D.C.

ECB (2012), Annual Report 2011, http://www.ecb.europa.eu/pub/pdf/annrep/ar2011ro.pdf

Ferreira, C. (2009), Public debt and economic growth: a Granger causality panel data approach, Technical University of Lisbon Working Papers no. 24, School of Economics and Management, https://www.repository.utl.pt/bitstream/10400.5/1863/1/getFile24.pdf

Greenidge, K., Craigwell, R., Chrystol, T., Drakes, L. (2012), Threshold effects of sovereign debt: Evidence from the Carribean, IMF Working Paper no. 157, Washington, D.C.

Hepp, R. (2008), Can debt relief buy growth?, Department of Economics, Fordham University, Discussion Paper Series no. 22, December 2008, http://www.fordham.edu /images/academics/graduate_schools/gsas/ economics/dp2008_22_hepp.pdf

Herndon, T., Ash, M., Pollin, R. (2013), Does High Public Debt Consistently Stifle Economic Growth? A Critique of Reinhart and Rogof, Political Economy Research Institute Working Papers Series no. 322, http://www.peri.umass.edu/fileadmin/pdf/working_papers/working_ papers_301350/WP322.pdf

Karagol, E. (2002), The causality analysis of external debt service and GNP: the case of Turkey, Central Bank Review, Research and Monetary Policy Department, Central Bank $f$ the Republic of Turkey, vol 2(1), 39-64.

Kumar, M.S., Woo, J., (2010), Public debt and growth, IMF Working Paper no. 174, Washington, D.C.

Misztal, P. (2010), Public debt and economic growth in the European Union, Journal of Applied Economic Sciences, vol. 5 (3), 292-302.

Moore, W., Chrystol, T. (2010), A meta-analysis of the relationship between debt and growth, International Journal of Development Issues, vol. 9(3), 214-225.

Panizza, U., Presbitero, A.F. (2014), Public debt and economic growth: Is there a causal effect?, Journal of Macroeconomics, vol. 41, September 2014, 21-41.

Panizza, U., Presbitero, A.F. (2013), Public debt and economic growth in advanced economies: a survey, MOFIR Working paper no. 78, http://docs.dises.univpm.it/web/quaderni/pdfmofir/ Mofir078.pdf

Patillo, C., Poirson, H., Ricci, L. (2004), What are the channels through which external debt affects growth?, IMF Working Paper no. 15, Washington, D.C.

Patillo, C., Poirson, H., Ricci, L. (2002), External Debt and Growth, IMF Working Paper no. 96, Washington, D.C.

Pescatori, A., Sandri, D., Simon, J. (2014), Debt and Growth: Is There a Magic Threshold?, IMF Working Paper no. 34, Washington, D.C. 
Reinhart, C.M., Rogoff, K.S. (2010a), Growth in a time of debt, American Economic Review, vol. 100(2), 573-578.

Reinhart, C.M., Rogoff, K.S. (2010b), Debt and growth revisited, MPRA Paper no. 24376, Munich University Library, Munich.

Schclarek, A. (2004), Debt and economic growth in developing and industrial countries, Working Paper no. 34, Department of Economics, School of Economics and Management, Lund University, http://ideas.repec.org/p/hhs/lunewp/2005o34.html

Scott, G. (1995), Foreign debt service and economic growth, Atlantic Economic Journal, vol. 23(2).

Smith, D.J., Hsing, Y. (1995), In search of an optimal debt ratio for economic growth, Contemporary Economic Policy, vol. 13(4), 51-59.

Weeks, J. (2000), Latin America and high performing Asian economies: growth and debt, Journal of International Development, 12(5), 625-654. 